\title{
Relacja na temat kościoła parafialnego w Nawarzycach i nieistniejącej świątyni w Lubczy z roku 1898
}

\section{Abstract}

\section{Report on the parish church in Nawarzyce and the non-existent temple in Lubcza of 1898}

\begin{abstract}
$\mathrm{T}$ he Roman Catholic parish in Nawarzyce (the Swiętokrzyskie Province, the Kielce Diocese) has a medieval origins (first mentioned in 1345). There is situated a brick church of St. Andrew the Apostle and St. Anna, built in the mid-seventeenth century as the foundation of the abbot of Jędrzejów, Bernard Łaszewski. The decoration of the temple is mostly from around 1780 and is in the Baroque and Rococo style. The interior hides several unique monuments, such as a stone bowl-shaped baptismal font, supported on the backs of lions, and a wooden boatshaped pulpit supported by four naked mermaids.

The document being the basis for below edition is stored in the Diocesan Archives in Kielce. This manuscript has not yet been published and exploited to a greater extent by historians. It is valuable because it contains many interesting, hitherto unknown facts about the church in Lubcza, destroyed by Calvinists during the Reformation, as well as the parish itself - incorporated into the Nawarzyce parish in 1690 .
\end{abstract}

Keywords: Nawarzyce parish, Lubcza parish, Kielce diocese, source edition, 1898 
STRESZCZENIE

$\mathrm{R}$ zymskokatolicka parafia w Nawarzycach (woj. świętokrzyskie, diecezja kielecka) ma średniowieczna metrykę (wzmiankowana po raz pierwszy w 1345 r.). Znajduje się tam murowany kościół pw. św. Andrzeja Apostoła i św. Anny, wybudowany $\mathrm{w}$ połowie XVII stulecia $\mathrm{z}$ fundacji opata jędrzejowskiego, Bernarda Łaszewskiego. Wystrój świątyni pochodzi w większości z około 1780 r. i utrzymany jest $\mathrm{w}$ stylu barokowo-rokokowym. Wnętrze skrywa kilka wysokiej klasy zabytków, takich jak kamienna chrzcielnica w formie misy, wsparta na grzbietach lwów, oraz drewniana ambona w kształcie łodzi, podtrzymywana przez cztery nagie syreny.

Przedstawione do edycji źródło przechowywane jest w zbiorach kieleckiego Archiwum Diecezjalnego. Rękopis ten nie był dotychczas publikowany i wyzyskiwany przez historyków w szerszym zakresie. Jest on o tyle cenny, że zawiera wiele interesujacych, nieznanych dotąd faktów na temat kościoła w Lubczy, zniszczonego przez kalwinów w okresie reformacji, jak również samej parafii - inkorporowanej do parafii nawarzyckiej w $1690 \mathrm{r}$.

Słowa kluczowe: parafia Nawarzyce, parafia Lubcza, diecezja kielecka, edycja źródłowa, 1898 rok

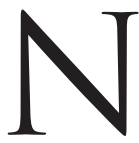

awarzyce to niewielka wieś w powiecie jędrzejowskim, leżąca nad rzeka Mozgawą. Początkowo należała ona w części do biskupstwa krakowskiego, w części zaś do świeckich właścicieli. W połowie XIII w. droga nadania i wykupu przeszła na własność klasztoru cystersów w Jędrzejowie. W XV stuleciu znajdował się tu drewniany kościół parafialny pw. św. Andrzeja Apostoła, powstały prawdopodobnie $z$ fundacji biskupa płockiego, Andrzeja z Brzeźnicy h. Gryf. Z przeprowadzonej w 1664 r. wizytacji wiadomo, że świątynia miała trzy ołtarze i była wewnątrz polichromowana $^{1}$.

Dnia 6 lutego 1741 r. kościół niemal doszczętnie spłonął, ocalała tylko zakrystia. W miejsce spalonego w latach 1747-1753

1 J. Wiśniewski, Historyczny opis kościołów, miast, zabytków i pamiatek w Jędrzejowskiem, Marjówka 1930 (reprint: Kielce 2000), s. 312; S. Borkiewicz, Z. Linowski, Monografia historyczna i gospodarcza powiatu jedrzejowskiego, Kielce 1937, s. 139; Br. Ch., Nawarzyce, [w:] Słowniku geograficznym Królestwa Polskiego i innych krajów słowiańskich, red. F. Sulimierski, B. Chlebowski, W. Walewski, t. VI, Warszawa 1885, s. 936. Por. też Opisanie historyczne kościoła parafialnego w Nawarzycach i nieistniejącego w Lubczy z miejscowych dokumentów i innych źródeł opracowane w 1898 roku, Archiwum Diecezjalne w Kielcach [dalej: ADK], Akta konsystorskie. Opis kościołów dekanatu jędrzejowskiego 1884-1898, sygn. OD-8/3, k. 8v-9. 
ówczesny kolator, opat jędrzejowski Bernard Łaszewski wystawił nowy, murowany $z$ cegły i kamienia ${ }^{2}$. Świątynia została ukończona i częściowo wyposażona w latach siedemdziesiątych i osiemdziesiatych XVII w. staraniem i sumptem miejscowego proboszcza, ks. Jana $z$ Matty Kotańskiego, który otynkował budynek zewnątrz i wewnątrz, sprawił marmurową posadzkę, chór organowy, wszystkie ołtarze i obrazy. Dzieło upiększania kościoła dopełnił ks. Adam Przerębski, opat komendatoryjny jędrzejowski i tamtejszy kolator, który $z$ masy spadkowej po ks. Kotańskim ufundował wspaniała ambonę, chrzcielnicę oraz konfesjonały. Konsekracji świątyni dokonał biskup kielecki Tomasz Teofil Kuliński 20 maja 1888 r., „przy licznym zjeździe duchowieństwa i wielkiego konkursu ludu”3, nadając jej wezwanie św. Andrzeja Apostoła i św. Anny ${ }^{4}$. Pięć lat później (1893) Nawarzyce nawiedził groźny pożar, który strawił gontowy dachy świątyni $z$ więźbą, wieżyczkę-sygnaturkę, dachy nad zakrystia, kruchtą i kaplica przedpogrzebową. Spalił się również dom służby kościelnej i dzwonnica (w ostatniej stopiły się trzy dzwony, w tym duży z 1747 r., wykonany w warsztacie znanego ludwisarza gdańskiego Johanna Gottfrieda Anthony'ego ${ }^{6}$. Jeszcze $\mathrm{w}$ tym samym roku, $\mathrm{z}$ inicjatywy miejscowego plebana ks. Kajetana Świderskiego i ze składek parafialnych, kościół został odbudowany i przywrócony do dawnej świetności. W 1894 r. wystawiono nowy dom dla służby kościelnej, odlano też trzy nowe dzwony ${ }^{7}$.

${ }^{2}$ W źródłach kościelnych zachowały się nazwiska muratorów. Byli to: Grzegorz Jajkiewicz vel Jajczyński, majster murarski z Krakowa, i Fryderyk Jędrowski z Książa Wielkiego. Por. edytowany dokument, k. 10.

${ }^{3}$ Ibidem, k. 12.

${ }^{4}$ Ibidem, k. 11v; J. Wiśniews ki, loc. cit. (tu informacja, że ambona, chrzcielnica i konfesjonały zostały ufundowane $z$ masy spadkowej po ks. Józefie Olechowskim, sufraganie krakowskim); Katalog zabytków sztuki w Polsce, t. III (Województwo kieleckie), red. J.Z. Łoziński, B. Wolff, z. 3 (Powiat jędrzejowski), oprac. T. Przypkowski, Warszawa 1957, s. 28. Por. też Inwentarz fundi instructi plebani w Nawarzycach w roku 1857 sporządzony, ADK, Akta konsystorskie parafii Nawarzyce 1806-1937, sygn. PN-5/1, k. 275.

${ }^{5}$ Wiadomość o tym trafiła na łamy stołecznej prasy. Por. Ks. S.S. [Stefan Stuczeń?], Pożar kościoła, „Słowo”, 27 V 1893, R. XII, nr 119, s. 2; Pożar kościoŁa, „Przegląd Katolicki”, 8 VI 1893, R. XXXI, nr 23, s. 363.

${ }^{6}$ Obszernie na temat tego warsztatu ludwisarskiego i jego wyrobów por. E. Wróblewska, Ludwisarnie Benningków, Wittwercków i Anthonych: studium z dziejów gdańskiego cechu odlewniczego, Warszawa 1999, s. 73-79 i n. Niestety, wśród prac J.G. Anthony'ego autorka nie odnotowała dzwonu w Nawarzycach.

${ }^{7}$ Opisanie historyczne kościoła parafialnego w Nawarzycach..., k. 12-13. 
Nawarzycki kościół jest budowlą barokową, orientowaną. Składa się $z$ dwuprzęsłowej nawy i krótkiego, węższego prezbiterium, zamkniętego absydą. Od strony północnej do prezbiterium przylega zakrystia, a do nawy skarbczyk i kaplica (pierwotnie przedpogrzebowa). Od południa, już w XX stuleciu, dostawiono kolejne przybudówki, m.in. kwadratowa kaplicę kopułowa, ufundowana przez rodzinę Wielowieyskich (właścicieli sąsiedniej Lubczy) jako forma ekspiacji za odstapienie członków rodu od Kościoła w czasach reformacji. Pierwotnie od strony zachodniej miał stanąć owalny portyk kolumnowy, lecz brak funduszy nie pozwolił na jego realizację. Prezbiterium i nawę przykrywa sklepienie kolebkowe $z$ lunetami, zakrystia, skarbczyk i kruchta maja sklepienia kolebkowo-krzyżowe. Wewnątrz, w zaokraglonych narożnikach nawy i między przęsłami, znajdują się pilastry dźwigające odcinki belkowania, na których wspieraja się gurty sklepienne. W przęsłach ściany północnej, pomiędzy pilastrami sa płytkie arkadowe wnęki, a w ścianie południowej przebite arkadowe otwory, łączace nawę $z$ przybudówką. Wnętrze oświetla sześć prostokątnych okien zamkniętych łukiem odcinkowym, $z$ których dwa usytuowane sa w prezbiterium, pozostałe zaś w nawie, po dwa od strony północnej i południowej. Niewielkie owalne okno znajduje się również nad wejściem głównym. Elewacje boczne sa dwukondygnacyjne, rozczłonkowane lizenami. Fasadę ujmuja na narożach pary pilastrów na wspólnych, wysokich cokołach, na osi których ustawione sa kamienne wazony. Dwuspadowy dach nawy - pierwotnie kryty gontem, obecnie blacha - przysłonięty jest dekoracyjnym szczytem $z$ wolutowymi spływami. Na kalenicy, mniej więcej $\mathrm{w}^{2 / 3}$ jej długości, mieści się wieżyczka $z$ sygnaturką zwieńczona krzyżem ${ }^{8}$.

Świątynia ma bogaty wystrój barokowo-rokokowy, pochodzacy w większości z około 1780 r. Składaja się na niego: ołtarz główny i dwa boczne, ambona, dwie chrzcielnice (drewniana i kamienna), chór organowy, konfesjonały, ławki, stacje Męki Pańskiej, epitafia, obrazy oraz freski. Ołtarz główny typu architektonicznego mieści w centralnej części obraz przedstawiający św. Joachima i św. Annę nauczająca młodziutka Maryję, na zasuwie zaś obraz Pana Jezusa na krzyżu. Flankuje go sześć korynckich kolumn, pomiędzy którymi ustawione sa figury św. Piotra i św. Pawła. W zwieńczeniu

${ }^{8}$ Katalog zabytków..., s. 28; J. Wiśniewski, op. cit., s. 312; Opisanie historyczne kościoła parafialnego w Nawarzycach..., k. 9v. 
widnieją Oko Opatrzności w glorii i rzeźby aniołów. W lewym bocznym ołtarzu znajduje się malarskie przedstawienie Świętej Rodziny (kopia obrazu renesansowego mistrza Rafaela Santi), zasuwane wizerunkiem św. Andrzeja Apostoła, a w zwieńczeniu obraz bł. Wincentego Kadłubka. Drugi $z$ bocznych ołtarzy zdobia obrazy: w centrum Pana Jezusa trzymajacego wstęge $z$ napisem „Pax vobis”, na zasuwie św. Sebastiana, wyżej zaś św. Jana Kantego. Oryginalna i unikatowa jest drewniana chrzcielnica w kształcie podłużnej czaszy, wspartej na czterech lwach, zdobiona od frontu płaskorzeźba Obrzezania w rokokowej ramie. Pokrywę dekorują liście akantu i rocaille, a wieńczy otwarta korona królewska. Czworoboczny cokół stanowiący podstawę chrzcielnicy oplata wąż z jabłkiem, symbolizujacym upadek pierwszych rodziców - Adama i Ewy. Nie mniej oryginalna jest drewniana ambona, ustawiona w arkadowej niszy na ścianie północnej nawy. Ma ona formę łodzi podtrzymywanej przez cztery rzeźbione syreny, wynurzające się z fal morskich. Na korpusie wyrzeźbiona została scena ukazujacca połów ryb przez Chrystusa i apostołów, na zaplecku gołębica Ducha Świętego w glorii, a w zwieńczeniu wyobrażenie Dobrego Pasterza9. Od zachodu mieści się chór muzyczny wsparty na dwóch kolumnach, o faliście wygiętym parapecie, zdobiony rokokowa dekoracja $z$ instrumentami muzycznymi. Na ścianach widnieja tablice epitafijne upamiętniające członków rodziny Wielowieyskich, miejscowych księży i donatorów ${ }^{10}$, jak również liczne obrazy. Godny odnotowania jest cudowny wizerunek Matki Boskiej Bolesnej, malowany na blasze („szkoła hiszpańska”), oraz cztery duże płótna w rokokowych ramach z 1770 r., ukazujące ewangelistów, pędzla krakowskiego artysty Franciszka Ignacego Molitora. Sklepienia i ściany pokrywa obfita dekoracja malarska o motywach roślinnych ${ }^{11}$.

${ }^{9}$ Ogólnie o ambonach w kształcie łodzi-okrętu por. J. S a mek, Ambony naves et naviculae w Polsce, [w:] Rokoko. Studia nad sztuka I połowy XVIII wieku. Materiały Sesji Stowarzyszenia Historyków Sztuki zorganizowanej wspólnie z Muzeum Ślaskim we Wrocławiu, Wrocław, październik 1968, Warszawa 1970, s. 219-250, http:/ / www.samkoviana.pl/1970-50-ambony-naves-et-naviculae-w-polsce/ (dostęp: 15 VIII 2021). Por. też T. Kow alski, Ambona łodziowa $w$ Sierpcu - geneza zjawiska artystycznego i jego sierpeckie echa, „Notatki Płockie. Kwartalnik Towarzystwa Naukowego Płockiego” 2015, t. LX, nr 1(242), s. 16-21.

10 Treść inskrypcji notuje J. Wiśn niews ki, op. cit., s. 313-314.

${ }^{11}$ Ibidem, s. 312-313; Katalog zabytków..., s. 28. Por. też Opisanie historyczne kościoła parafialnego w Nawarzycach..., k. 10v-11v. 
Przedłożone do edycji źródło przechowywane jest w Archiwum Diecezjalnym w Kielcach, w teczce Akta konsystorskie. Opis kościołów dekanatu jędrzejowskiego 1884-1898, oznaczonej sygnatura OD-8/3. Dokument został sporządzony na zlecenie władz kościelnych w 1898 r. przez ówczesnego proboszcza parafii nawarzyckiej, ks. Kajetana Świderskiego. Spisano go w języku polskim na kartach formatu A4, zapisanych obustronnie, pierwotnie niepaginowanych (obecnie k. 92-124v/1-33v), zszytych razem i oprawionych. Pismo jest staranne, kursywne, $z$ nielicznymi skreśleniami. Tekst został opatrzony przypisami autorskimi (objaśnienia, bibliografia tematu), mieszczacymi się u dołu strony. Źródło to nie było wcześniej publikowane ani też wykorzystywane przez historyków w szerszym zakresie ${ }^{12}$.

Rękopis składa się $z$ trzech części. Pierwsza zawiera informacje na temat nieistniejącego dziś kościoła w Lubczy, który w połowie XVI w. został zniszczony przez kalwińskich właścicieli wsi - Krzysztofa i Stanisława Spinków (Wspinków), a pod koniec następnego stulecia rozebrany, parafia zaś wcielona do nawarzyckiej. Część druga dotyczy parafii w Nawarzycach. Zamieszczono w niej wiadomości na temat wsi parafialnych, przedstawiono dzieje miejscowego kościoła, opisano jego architekturę i wystrój wnętrza, podano wreszcie informacje na temat odpustów i uposażenia. Ostatnia część, pominięta w edycji ze względu na szczupłość miejsca, zawiera informacje na temat życia i działalności kolejnych plebanów nawarzyckich, administrujących parafią od początku XVI do końca XIX stulecia. Źródło to w istotny sposób wzbogaca naszą wiedzę o parafii i kościele w Nawarzycach, które w dalszym ciagu czekaja na monograficzne opracowanie.

$$
* * *
$$

Edycja źródłowa została przygotowana zgodnie $z$ wytycznymi zawartymi w instrukcji wydawniczej Ireneusza Ihnatowicza ${ }^{13}$. Zmodernizowano pisownię wyrazów, ortografię imion oraz interpunkcję.

${ }^{12}$ Zdaje się, że korzystał $z$ niego jedynie ks. J a n Wiśn niews ki (op. cit., s. 312319), sporządzając opis parafii w Nawarzycach i Lubczy.

${ }^{13}$ I. I h nat ow icz, Projekt instrukcji wydawniczej dla źródet historycznych XIX i początku XX wieku, „Studia Źródłoznawcze” 1962, t. VII, s. 99-124. 
Ujednolicono zapis jednostek monetarnych, powierzchni i wagi. Rozwiązano większość skrótów, pozostawiając jedynie najbardziej popularne jak: ks. - ksiądz, p. - pan/-i, św. - święty/a, XX. - księża. W nawiasach prostokatnych zaznaczono poczatek danej strony, opustki pisarza oraz lekcje watpliwe. W przypisach rzeczowych objaśniono postaci i miejscowości występujące w podstawie wydania, jak również trudniejsze terminy. Zachowano oryginalny układ tekstu.

\section{TEKST ŹRÓDEOWY}

\section{Opisanie historyczne kościoła parafialnego w Nawarzycach i nieistniejącego w Lubczy, z miejscowych dokumentów i innych źródel opracowane w 1898 roku}

Oryg.: Archiwum Diecezjalne w Kielcach, Akta konsystorskie. Opis kościołów dekanatu jędrzejowskiego 1884-1898, sygn. OD-8/3, k. 92-106v [1-14v].

[k. 93] Wstęp

Wieś Nawarzyce $z$ kościołem parafialnym (powiatu jędrzejowskiego, guberni kieleckiej) leży w odległości jednego dobrego staja nad strumykiem albo rzeczka zwana Mozgawa, wpadająca pod Niegosławicami w rzekę Mierzawę ${ }^{1)}$. Tak podaja dawne tutejsze inwentarze kościelne.

Parafia obecna, licząca ogółem 2743 dusz, składa się właściwie z dwóch parafii: $z$ nawarzyckiej i byłej lubeckiej. Całość jej stanowią następujące wsi: Brzezinki; Konary z przyległościami swymi Dębiany; Lubcza z przyległościami: Ewcin, Janów, Przezwody i Wola Lubecka; Nawarzyce; Niegosławice z przyległościami: Przyrąb i Sielce; Sadki.

1) Błędną wiadomość zamieszczono w „Słowniku geograficznym”, t. VI, s. 936, że Nawarzyce leżą nad rzeką Mierzawą. 
Według wizyty Oborskiego ${ }^{14} 1664$ r. należały do tej parafii Zagaje $^{15}$ (obecnie w parafii mierzwińskiej). Taż wizyta wylicza wieś parafialna zwaną Niegoszowicami, której już na początku XVIII wieku nie spotykamy w metrykach kościelnych i obecnie pamięć o niej zaginęła. Zdaje się, że za czasów Adama Przerębskiego, opata komendatoryjnego jędrzejowskiego ${ }^{16}$, w miejsce Niegoszowic powstał Przeręb, dzisiejszy Przyrąb, jak powstał i inny folwark zwany Adamowem.

Pomówimy wprzódy o parafii lubeckiej, a następnie o nawarzyckiej.

\section{[k. 1v] Część I}

Opis kościoła w Lubczy

(Lubza, Lubicha, Lijupcza)

Treść: o kościele - jego uposażeniu - plebani lubeccy - smutny los

[k. 1v] W dawnej a bardzo rozległej diecezji krakowskiej istniały trzy parafie lubeckie. Pierwsza Lubcza leżała w Galicji w okolicy miasta Pilzna. Druga na Śląsku w okolicy Woźnik i trzecia w dekanacie jędrzejowskim.

W tej to ostatniej znajdował się kościół parafialny $z$ drzewa pod tytułem św. Małgorzaty Panny i Męczennicy według [Jana] Długosza „Liber beneficiorum”, t. II, s. $72^{17}$ - a św. Agnieszki Panny i Męczennicy według niniejszych dokumentów ${ }^{18}$. Wznieśli go i upo-

${ }^{14}$ Mikołaj Oborski h. Pierzchała (1611-1689), biskup pomocniczy krakowski w latach 1658-1689, tytularny biskup leodycejski (1658). Por. J. Bieniarzówna, Oborski Mikołaj, [w:] Polski słownik biograficzny [dalej: PSB], t. XXIII, Wrocław 1978, s. 449-450; P. Nit ecki, Biskupi Kościoła w Polsce w latach 9651999. Słownik biograficzny, wyd. 2 poprawione i uzupełnione, Warszawa 2000, s. 315-316.

${ }^{15}$ Zagaje, wieś w powiecie jędrzejowskim, w dawnej guberni kieleckiej.

${ }^{16}$ Adam Przerębski h. Nowina, kanonik krakowski, włocławski, pisarz wielki koronny (1790), opat komendatoryjny w klasztorze cystersów Jędrzejowie w latach 1760-1811. Por. W. Bukows ki, Katalog opatów jędrzejowskich. Próba ustalenia chronologii, [w:] Cystersi w Polsce. W 850-lecie fundacji opactwa jędrzejowskiego, red. D. Olszewski, Kielce 1990, s. 201.

17 Joannis Dlugossii Senioris Canonici Cracoviensis Opera omnia (= Jana Długosza kanonika krakowskiego dzieła wszystkie), vol. VIII (Liber beneficiorum dioecesis cracoviensis nunc primum e codice autographo editus, t. II), ed. A. Przeździecki, Cracoviae 1864, s. 72 .

${ }_{18}$ Chodzi tu m.in. o akta wizytacji dekanatu krakowskiego, przeprowadzonej z polecenia biskupa Jerzego Radziwiłła w latach 1595-1598. Por. D. Szy mański, Wezwania kościołów parafialnych $w$ diecezji krakowskiej $w$ końcu XVI w., „Roczniki Humanistyczne” 1993, t. XLI, z. 2, s. 147. 
sażyli niezawodnie miejscowi dziedzice Lubczy nie wiadomo kiedy, gdyż oni byli kolatorami i patronami. Najdawniejsza wiadomość o tutejszym kościele mamy $z$ roku 1326.

Wizyta Potkańskiego ${ }^{19}$ w roku 1747 pisze o miejscu, gdzie stał kościół w tych słowach: „stał gdzie cmentarz, $z$ mała bramka, w środku wsi, blisko dworu. Plebania była blisko tegoż cmentarza, a miejsce jej ukazywały duże drzewa; na którem to miejscu wówczas można było widzieć ogród warzywny dworski (hortus olitorius)". Wobec tak wyraźnego orzeczenia nie wytrzymuja krytyki podania miejscowe obecne, jakoby kościół stał na górze zwanej Okraglica. Twierdzenia o znajdowaniu się na niej grobów czy piwnic, żelaznych drzwi itd. uważam za czcze baśnie, jakich w ogóle pełno między ludem, zamieszkałym blisko nieistniejących kościołów, rozwalonych zamków. Bo pytam się: któż to kiedy [k. 2] widział lub znalazł? A gdyby i rzeczywiście podobne rzeczy znajdowały się na Okraglicy, mogły to być groby arianów, zmarłych w Lubczy.

Do parafii, oprócz wsi Lubczy, należały Przezwody i Wola Lubecka. Długosz („Liber beneficiorum”, t. II, s. 72 i 113) zalicza jeszcze wieś Stępocice ${ }^{20}$, lecz w miejscowych dokumentach nie ma o tym żadnej wzmianki.

Jak Lubcza jest stara miejscowościa, widzimy $z$ tego, że niejaki Wincenty, syn Dywissa $z$ Lubczy ${ }^{21}$ sprzedał Teodorykowi, opatowi jędrzejowskiemu ${ }^{22}[\mathrm{w}] 1234 \mathrm{r}$. dziedzictwo swoje, to jest młyn $z$ przyległościami w Skoruszkowicach ${ }^{23}$ za 20 grzywien srebra $z$ dodaniem jednego konia, jednej krowy i nowego płaszcza ${ }^{2)}$.

2) „Kodeks dyplomatyczny Małopolski”, t. III, s. 23. Według objaśnień p. F. Piekosińskiego do tego aktu sprzedaży, Skoruszkowice leżały na lewym brzegu rz. Mierzawy, a graniczyły z Olbracicami. Dziś nie ma tu tej miejscowości. Młyn w Niegosławicach, własność niegdyś z wsią klasztoru jędrzejowskiego, i chociaż leży na lewym brzegu rz. Mierzawy, nie graniczy z Olbracicami. Przedzielają go Konary, Strzeżkowice, mające też swoje młyny.

${ }^{19}$ Franciszek Potkański (ok. 1710-1789), kanonik łucki, chełmski, sandomierski i krakowski, sufragan krakowski w latach 1753-1786. Por. W. Baczkowska, W. Szczygiels ki, Potkański Franciszek, [w:] PSB, t. XXVII, Wrocław 1983, s. 722-724; P. Nitecki, op. cit., s. 357-358.

${ }^{20}$ Stępocice, wieś w obecnym powiecie pińczowskim, w województwie świętokrzyskim.

${ }^{21}$ Dziwisz z Lubczy, miejscowy dziedzic. Por. J. Wiśn niewski, op. cit., s. 314; S. Borkiewicz, Z. Linowski, op. cit., s. 81 .

${ }^{22}$ Teodoryk, opat jędrzejowski w latach 1213-1246. Por. W. Bukowski, op. cit., s. 185-186; M. Zd a n ek, Opat Teodoryk i cystersi jedrzejowscy w 1. połowie XIII wieku, [w:] Cystersi - Jędrzejów-Ziemia Jędrzejowska. Wspólne dziedzictwo, red. K. Ślusarek, Jędrzejów-Kraków 2006, s. 52.

${ }^{23}$ Skoruszkowice, dawniej wieś nad rzeką Mierzawa, obecnie nieistniejąca. 
Z Lubczy pochodził Mikołaj24, prepozyt kielecki około roku 1420. $Z$ różnymi dziedzicami lubeckimi spotkamy się nieraz w dalszym ciagu niniejszego opowiadania. Tu tylko nadmieniam, że już w roku 1756 Lubcza zostawała w rękach familii szlacheckiej Wielowiejskich $^{25}$, to jest Adama Wielowiejskiego ${ }^{26}$, majora dragonów wojsk koronnych - i dotąd zostaje.

O Woli Lubeckiej to mamy do powiedzenia, że Zbigniew, biskup laodycejski, sufragan krakowski ${ }^{27}$, Klemens, Mikołaj, kanonik krakowski, i Pełka, bracia rodzeni, synowie Zbigniewa $z$ Łapanowa, dziedzice Woli Lubeckiej sprzeczali się między sobą w latach 13951399 [k. 2v] o działy majątkowe ${ }^{3)}$ i o granice między Sędowicami a Wola Lubecka $z$ Mikołajem, opatem mogilskim ${ }^{4}$. W owe czasy egzystował na Woli Lubeckiej młyn, z którego dzisiaj nawet śladu nie ma. Oprócz tej wsi pomienieni bracia posiadali jeszcze inne dobra, jak Kobylecz ${ }^{28}$, Stradlicze, Chudą Wolę, Grabie i Dymlin.

\section{O uposażeniu}

Według „Liber Retaxationum” $z$ roku $1529^{29}$ uposażenie plebana lubeckiego składało się: $z$ dziesięciny wytycznej po całej wsi Lubczy i Woli Lubeckiej; $z$ dziesięciny na gruntach dworskich Powęchadłowskich i trzech kmiecych; $z$ dziesięciny wytycznej w obojgu Lubochowach $z$ gruntów pięciu $\mathrm{kmieci}^{5)} ; \mathrm{z}$ dziesięciny wytycznej po

3) „Pomniki starodawne prawa polskiego” p. Helcla, t. I, s. 46, 56, 67, 73, 85.

4) „Zbiór dyplomów klasztoru mogilskiego”, s. 13, 88.

5) Wieś Lubochowa leżała w obwodzie krakowskim.

${ }^{24}$ Mikołaj z Łapanowa, syn Zbigniewa, kanonik krakowski (1390), prepozyt kielecki. Ostatni raz występuje w dokumencie z 1427 r. Por. M.D. Kowalski, Zapomniany kalendarz-nekrolog kapituły krakowskiej z XV wieku, „Nasza Przeszłość" 1997, t. LXXXVII, s. 134. Por. też S. Borkiewicz, Z. Linowski, op. cit., s. 81 .

${ }^{25}$ O tej familii por. K. Niesiecki, Herbarz polski, t. IX, wyd. J.N. Bobrowicz, Lipsk 1842, s. 294.

${ }^{26}$ Adam Wielowiejski vel Wielowieyski (1835-1901), właściciel majątku Lubcza, prezes Towarzystwa Kredytowego Ziemskiego w Kielcach (1892-1901).

${ }_{27}$ Zbigniew $z$ Łapanowa, syn Zbigniewa, sufragan krakowski od około 1395 r. Por. P. Nitecki, op. cit., s. 511. Por. też S. Borkiewicz, Z. Linowski, op. cit., s. 81.

${ }^{28}$ Kobylec, wieś w obecnym powiecie bocheńskim, w gminie Łapanów.

${ }^{29}$ Por. Ksiegga dochodów beneficjów diecezji krakowskiej z roku 1529 (tzw. Liber retaxationum), wyd. Z. Leszczyńska-Skrętowa, Wrocław 1968, Materiały Komisji Nauk Historycznych, nr 13. 
gruntach dworskich w Niegosławicach, o którą toczył się wówczas spór między plebanem lubeckim a opatem jędrzejowskim ${ }^{6)}$; nadto $z$ kolędy pieniężnej i dziesięciny konopnej.

$Z$ wyroków sądowych $z$ późniejszych czasów okazuje się, że do probostwa lubeckiego należały też od bardzo dawna pewne grunta w Lubczy („agros amplos”, zwane w roku 1747 Plebanka) - sadzawka na Woli Lubeckiej i łąki leżące przy drodze, która prowadzi z Niegosławic do Lubczy. Wówczas, według „Liber Retaxationum”, lepiej było uposażone probostwo lubeckie niż nawarzyckie, bo o 12 grzywien i 28 gr więcej. [k. 3]

\section{Plebani lubeccy wiadomi}

Albert od dochodu $z$ beneficjum, szacowanego na pić i pół grzywien, w roku 1326 zapłacił świętopietrza kolektorom tegoż 7 skojców i 22 denary. Tyleż miał płacić na druga ratę. Razem probostwo tutejsze płaciło 15 skojców i 22 denary ${ }^{7}$.

Adam, rządca kościoła w Lubczy, był świadkiem przy akcie kupna wsi Ostrowa przez Jana Jurę, wojewodę sandomierskiego, w dniu 30 września 1348 r. ${ }^{8)} 30$

Paweł ze Skrzynna ${ }^{31}$. Za czasów jego, mianowicie [w] 1529 r. nastapiła retaksacja probostwa.

Stanisław $^{32}$. Przez prokuratora swego Szymona $z$ Kalisza w dniu 16 października 1533 r. pozwał przed Mikołaja Bedleńskiego ${ }^{33}$, scholastyka krakowskiego i wikariusza in Spirit jeneralnego, Jana Dąga i Jakuba Gajosza, karczmarza z Niegosławic, o nieoddanie dziesięciny wytycznej. $Z$ ich strony, jak również ze strony Wojciecha

6) Niegosławice przeszły na własność klasztoru jędrzejowskiego [w] $1192 \mathrm{r}$. Można przypuszczać, że już wtenczas stał kościół w Lubczy, skoro plebani jego mieli prawo do dziesięciny dworskiej w Niegosławicach mimo zmiany ich właściciela i zmuszeni byli zasłaniać się prawem przeciw uroszczeniom opatów.

7) „Monumenta” Theinera, t. I, s. 242.

8) „Kodeks dyplomatyczny” Bartoszewicza, s. 223.

${ }^{30}$ Obaj plebani - Albert i Adam wzmiankowani sa przez ks. J. Wiśn niews kiego (op. cit., s. 314-315).

${ }^{31}$ Paweł ze Skrzynna, skądinąd nieznany.

${ }^{32}$ Por. J. Wiśniewski, op. cit., s. 315.

${ }^{33}$ Mikołaj Bedleński (zm. 1540), scholastyk, wikariusz generalny krakowski. Wzmiankowany przez K. Niesieckiego, op. cit., t. II, Lipsk 1839, s. 88. 
z Kłodawy, opata jędrzejowskiego ${ }^{34}$, był prokuratorem Stanisław Brzezicki ${ }^{35}$, magister. Pozwani tłumaczyli się na sądzie, że owa dziesięcina ex antiquo należała do klasztoru jędrzejowskiego $z$ powodu, że dworskie grunta niegosławskie tamże należą, a oni sa parafianami nawarzyckimi, nie lebeckimi. Polecono obydwom stronom spornym dowodzić swoich praw w następnym terminie sądowym.

W inwentarzu kościelnym nawarzyckim $z$ roku 1792, a mianowicie w dziale „sumariusz praw i dokumentów kościoła” czytamy, iż był wtedy dokument treści, jako [k. 3v] powyższy Stanisław, pleban lubecki, miał sprawę w Oficjalacie Krakowskim $z$ Wojciechem $z$ Kłodawy, opatem jędrzejowskim, $z$ powodu dziesięciny $z$ pewnych gruntów wsi Lubczy i Zagaje przez kmieci z Niegosławic obsianych i na dniu 10 marca 1554 r. uzyskał dekret, przysądzający takową kościołowi w Lubczy.

\section{Smutny los kościoła}

Nie wiadomo, jak rychło po roku 1554 Krzysztof i Stanisław Spinkowie, dziedzice Lubczy ${ }^{36}$, dali posłuch szerzącym się w kraju nowościom religijnym, a zostawszy heretykami, zrobili $z$ miejscowym kościołem to, co i inni gdzie indziej im podobni. Według wizyty Krzysztofa Kazimierskiego ${ }^{37}$ [w] 1596 r., kościół parafialny rozwalili i ze wszystkiego złupili. Na gruntach plebańskich osiedlono włościanina. Dla swoich potrzeb religijnych postawili w Lubczy zbór, o którym wspomina [Józef] Łukaszewicz, s. 26138, lecz nie

${ }^{34}$ Wojciech $z$ Kłodawy, opat jędrzejowski w latach 1530-1560. Por. W. Bukowski, op. cit., s. 195; J. Wiśniewski, op. cit., s. 62. Pochowany został na cmentarzu przy kościele klasztornym. Treść inskrypcji nagrobnej notuje: Corpus inscriptionu Poliniae, t. I (Województwo kieleckie), red. J. Szymański, z. 2 (Jędrzejów i region jędrzejowski), wydała, wstępem i komentarzem opatrzyła B. Trelińska, Kielce 1978, s. 49 (nr 21).

35 Stanisław Brzezicki, skądinąd nieznany.

${ }^{36}$ Por. I. Kaniewska, Spinek (Wspinek) Stanisław, [w:] PSB, t. XLI, Warszawa-Kraków 2002, s. 107-109.

${ }^{37}$ Krzysztof Kaźmierski vel Kazimierski (zm. po 1618), kanonik tarnowski i krakowski, biskup kijowski, przeprowadził wizytację diecezji krakowskiej na polecenie biskupa Jerzego Radziwiłła. Por. W. Urban, Kazimirski (Kazimierski) Krzysztof, [w:] PSB, t. XII, Wrocław-Warszawa-Kraków 1966-1967, s. 292-293; P. Nitecki, op. cit., s. 199.

38 J. Łukaszewicz, Dzieje kościołów wyznania helweckiego w dawnej Małej Polsce, Poznań 1853, s. 361-362. 
na miejscu, gdzie stał kościół. O budulcu $z$ rozwalonego kościoła powiada taż wizyta, że zalega dziedziniec dworski ${ }^{9}$.

O tym i o miejscu, gdzie stał kościól, znajdują się w dokumentach kościelnych nawarzyckich dwa świadectwa. Jedno $z$ nich, to jest zeznanie na inkwizycji sadowej świadka w pewnej sprawie ks. Fabro[k. 4]wicza, plebana nawarzyckiego ${ }^{39} z$ Maciejem Korzeńskim, dziedzicem Lubczy ${ }^{40}[\mathrm{w}] 1683$ r., zamieścimy tutaj. Oto, co pracowity Adam Brozek $z$ Niegosławic ${ }^{41}$, lat 84, po złożeniu cielesnej przysięgi zeznał:

„Urodziłem się w Niegosławicach i tam przez wiek mój mieszkając, nigdy inaczej od nikogo nie słyszałem, tylko że w Lubczy kościół był $z$ dawna, który byli kiedyś dawni Panowie Szpinkowie haeretycy rozburzyli. Ja jednak tego kościoła nie pamiętam, ale ociec żony mojej Zasadzeń Bartłomiej z Lubczy ${ }^{42}$, poddany, powiedał mi dawno jeszcze przed lat 30, iż w tym kościele bywał, ale nie był za niego spustoszał. I stado końskie w nim Panów Spinków zawierano. Ja jednak drzewo $z$ tego kościoła pamiętam leżace nad sadzawką. Gdzie się potym podziało, nie wiem. Plac, na którym kościół stał, pamiętam i widuję go, idąc drogą. Na tym tedy placu chciał Xiądz Pleban Nawarzycki przed dwiema lat ${ }^{10)}$ Bożą mękę stawiać... itd.".

(O dalszym losie parafii lubeckiej będzie w opisie kościoła nawarzyckiego).

9) „Dzieje reformacji” przez ks. Bukowskiego, t. I, s. 407, 641. Chociaż powtórzyliśmy za ks. Bukowskim, że miał stać w Lubczy zbór, co też twierdzi i obecny jej p. dziedzic, jednak podaję w wątpliwość podobną wersję, a podaję na tej zasadzie, że wizyta Potkańskiego [z] 1747 r. powiada, że nie masz w tej parafii żadnego krypla, bóżnicy innego wyznania, a kalwini odbywaja swoje zgromadzenia (conventicula) u szlachetnej Ożarowskiej, kalwinki, dziedziczki dóbr Lubcza. Toż samo, z zamilczeniem już o kalwinach, powtórzono w bardzo dokładnym opisie kościoła $1792 \mathrm{r}$.

10) To jest w czwartek po św. Idzie opacie $1681 \mathrm{r}$.

${ }^{39}$ Andrzej Fabrowicz, pleban w Nawarzycach i administrator beneficjum w Lubczy w latach 1669-1703. Por. J. Wiśniewski, op. cit., s. 316. Wiadomości biograficzne por. Opisanie historyczne kościoła parafialnego w Nawarzycach..., k. $17 \mathrm{v}-20 \mathrm{v}$.

${ }^{40}$ Por. S. Borkiewicz, Z. Linowski, op. cit., s. 82.

41 Adam Brożek, kmieć $z$ Nagłowic, skądinąd nieznany.

42 Bartłomiej Zasadzeń, włościanin z Lubczy, skądinąd nieznany. 


\begin{abstract}
[k. 4v] Część II
Opis kościoła w Nawarzycach

Treść: krótkie wiadomości o wsiach parafialnych - historia kościoła - o odpustach - o uposażeniu - spis wiadomych plebanów i ich działalność
\end{abstract}

\title{
Nawarzyce \\ (Navariz - Navariche)
}

Powiedzieliśmy we wstępie, opierając się na miejscowych inwentarzach, że Nawarzyce leżą o staje jedno wielkie, z prawej strony, nad rzeką Mozgawa, wpadającą w rzekę Mierzawę pod Niegosławicami. Dla pracujących na polu historii krajowej szczegół to ważny. Ponieważ w całym powiecie jędrzejowskim nie ma ani miejscowości, ani rzeczki z nazwą Mozgawa, więc to tu gdzieś, na tych równinach, pełnych jeszcze dzisiaj trzęsawisk i topieli (brak tylko „krzewiastych zarośli”) - dnia 13 września 1195 r. stoczona była pamiętna w dziejach bitwa o dzielnicę krakowska, opisywana przez kronikarzy, między Mieszkiem Starym a Leszkiem Białym (małoletnim), między Wielkopolanami a Krakowianami i ich sprzymierzeńcami.

Pan Stanisław Smolka $z$ właściwym sobie talentem opisał obszerniej przebieg zawziętej walki, tam też odsyłam ciekawych ${ }^{11}$. Tu tylko ośmielam się powtórzyć za tym Szanownym Autorem, że w czasie bitwy padł syn Mieszka, Bolesław ${ }^{43}$, dzida przeszyty; sam Mieszko [k. 5] Stary został ciężko ranny; znaczna część ruskich posiłków umknęła $z$ pola bitwy przy pierwszym starciu, kniaź Roman Włodzimierski rzucił się zrazu śmiało w wir bojowy, ale ciężko ranny $z$ resztą wojsk swoich w ucieczce szukał ocalenia. Śląscy książęta Mieczysław Raciborski ${ }^{44}$ i Jarosław Opolski ${ }^{45}$ za późno przybyli dla swych sprzymierzeńców; zastali tylko pobojowisko trupami zasłane. Natarł na nich jeszcze $z$ małych hufcem rycerstwa Goworek, wojewoda sandomierski ${ }^{46}$, Kazimierzowych dzieci wierny sługa, ale uległszy przeważnej sile Ślązaków, niewolą przypłaciła swoją odwagę.

11) „Mieszko stary i jego wiek”, s. 370.

${ }^{43}$ Bolesław Mieszkowic, książę kujawski. Por. Z. Kozłowska-Budkowa, Bolesław (1159-1195), [w:] PSB, t. II, Kraków 1936, s. 262.

${ }_{44}$ Mieczysław I (zm. 1211), książę Raciborza i Opola, syn Władysław Wygnańca.

45 Jarosław Opolski, najstarszy syn Bolesława I Wysokiego i jego pierwszej żony Zwienisławy, książę opolski od 1173 r., biskup wrocławski od 1198 r.

${ }^{46}$ Gworek h. Rawicz, wojewoda sandomierski i kasztelan krakowski. 
Robię nacisk na rzeczkę Mozgawę dlatego, gdyż p. [Arndt], zapewne przez niewiadomość o istnieniu tu jeszcze dzisiaj tego strumyka, chce mieć miejsce owej bitwy w okolicach Radomia, a p. Stenzel robi z Mozgawy rzekę Skawę koło Zatoru ${ }^{12)}$.

Od rzeki nazwano też niegdyś tutejszą miejscowość Mozgawa. Między innymi tak o tym napisał Wincenty Kadłubek: „est in Cracoviensi provincia locus, a nomine fluvii, Mosgava dictus, ab Andreoviensi coenobio non longe dystans"13). (Licza 15 wiorst).

Oprócz powyższej cytaty mamy jeszcze inny dowód na to, że istniała tu siedziba ludzka pod nazwa Mozgawy.

Na początku XIII wieku żyła w Krakowskiej Zie[k. 5v]mi pewna rodzina szlachecka herbu Gryf, bogata w liczne włości ziemskie, ale przede wszystkim bogata $\mathrm{w}$ cnoty chrześcijańskie. Historia przekazała potomności $z$ tej rodziny trzech braci: Klemensa, Jana i Andrzeja, synów Marka, wojewody krakowskiego. Klemens hrabia na Ruszczy i Klimontowie, kasztelan krakowski ${ }^{47}$, z żoną swoja Racława fundował klasztor panien benedyktynek w dziedzicznej wsi Staniątkach i takowy kilku wsiami uposażył. W nim wiodła żywot zakonny córka ich Wisenega i była ksienia klasztoru ${ }^{14}$. Do fundacji przyłożyli się bracia Jan, kasztelan cieszyński ${ }^{48}$, i Andrzej, scholastyk krakowski i kanonik płocki ${ }^{49}$, zapisujac pewne wsi.

Ów Andrzej, będąc jeszcze kanonikiem krakowskim, podróżował do Rzymu z Iwonem, biskupem krakowskim ${ }^{50}$. [Bartosz] Paprocki (s. 500) mówi, że pielgrzymkę ową odbywał Iwo pieszo. Gdy w podróży Iwo zmarł [w] 1229 r., papież Grzegorz IX oddał stolicę biskupią krakowska Andrzejowi; lecz on dowiedziawszy się,

12) Monumeta H. Bielowskiego, t. III, s. 484.

13) Tamże, t. II, s. 433.

14) „Herby rycerstwa” p. Paprockiego, s. 124, 125 i „Klejnoty [stołecznego] miasta Krakowa” p. Pruszcza, s. 183.

${ }^{47}$ Klemens z Brzeźnicy, Klemens Klimontowic (zm. 1241), wojewoda opolski, a następnie kasztelan krakowski, fundator klasztoru cysterek w Łubicach i klasztoru bernardynek w Staniątkach. Por. M.L. Wój ci k, Ród Gryfitów do końca XIII wieku. Pochodzenie-genealogia-rozsiedlenie, Wrocław 1993, s. 44 i n.

48 Jan Klomontowic (zm. po 1243), kasztelan torzecki i cieszyński. Por. ibidem, s. $44-50$.

49 Andrzej z Brzeźnicy (zm. 1244), scholastyk krakowski, biskup płocki od 1239 r. Por. J. Umiński, Andrzej I h. Gryf zw. Krakowczykiem, [w:] PSB, t. I, Kraków 1935, s. 102; P. Nitecki, op. cit., s. 7-8.

50 Iwo Odrowąż (ok. 1160-1229), biskup krakowski od 1218 r. Por. P. Nitecki, op. cit., s. 158-159. 
że kapituła krakowska obrała Wisława ${ }^{51}$, protegowanego przez Henryka Brodatego, ustapił, a potem został biskupem mazowieckim, czyli płockim [w] 1239 r. $^{15}$ )

Wkrótce potem Andrzej, już jako biskup płocki, i brat jego Jan zrobili jakąś zamianę z Prandotą, [k. 6] biskupem krakowskim ${ }^{52}$, i kanonikami katedry św. Wacława, moca której za pewne wsi wzięli od biskupa i kanoników: dziesięciny na Mozgawie i wieś Liziny (dotąd nieodgadniona) całkowicie $z$ kościołem św. Klemensa i wszystkimi dziesięcinami do tegoż kościoła należącymi. Na co dał przywilej Konrad, książę krakowski i łęczycki w roku 124216). Mamy więc dowód, że Mozgawa była siedzibą ludzką, skoro z niej brano dziesięciny.

Bardzo prawdopodobne, że owa siedziba, dotąd nosząca miano Mozgawy (kto wie, czy nie tu leżały i owe zaginione Liziny?), w czasie pierwszego napadu Tatarów około roku 1240 została zniesiona, spalona, jak wiele innych wsi i miast. Po nowej kolonizacji nazwano nowo powstałą wieś Nowarzycamu, Nawarzycami, a dziedzicem jej spotykamy wyżej już wspomnianego Jana, kasztelana cieszyńskiego.

Ten to Jan darował wieś swoją Nawarzyce, jako jałmużnę, klasztorowi jędrzejowskiemu; a darowiznę tę, pod wezwaniem kary Bożej na przeciwników, zatwierdził brat Jana Andrzej, biskup płocki. Tak zeznawał na wiecu w Koniemłotach ${ }^{53}$ przed Bolesławem Wstydliwym dnia 30 marca 1246 r. Sulisław, kantor płocki i kanonik krakowski, syn rzeczonego Jana, który o stryju swoim, biskupie Andrzeju, wyrażał się jako już zmarłym ${ }^{17}$.

[k. 6v] Mimo tak wyraźnego zapisu zachodziły jakieś nieporozumienia między klasztorem jędrzejowskim a dziekanem i kapituła

15) „Encyklopedia kościelna”, t. IX, s. 613.

16) „Kodeks dyplomatyczny” Bartoszewicza, s. 434.

17) „Kodeks dyplomatyczny Małopolski”, t. III, s. 33, 34.

${ }^{51}$ Wisław z Kościelca (zm. 1242), biskup krakowski od 1229 r. Por. ibidem, s. 483; K.R. Proko p, Poczet biskupów krakowskich, Kraków 1999, s. 58-60.

${ }^{52}$ Prandota h. Odrowąż (ok. 1200-1266), kanonik sandomierski i krakowski, biskup krakowski (od 1242 r.). Por. S. Trawkowski, Prędota (Prandota), mylnie Jan P-a, [w:] PSB, t. XXVIII, Wrocław 1984-1985, s. 447-452; K.R. Proko p, op. cit., s. 61-64; P. Nite cki, op. cit., s. 359; J. Wiśn niew ski, Katalog prałatów $i$ kanoników sandomierskich od 1186 do 1926 r. tudzież sesje kapituły sandomierskiej od 1581 do 1866 r., Radom 1928, s. 87-88.

${ }^{53}$ Koniemłoty, wieś w obecnym województwie świętokrzyskim, około $5 \mathrm{~km}$ na południowy zachód od Staszowa. 
krakowska, dowodzaca, że ona za własne pieniądze nabyła dla siebie od Andrzeja, scholastyka jeszcze krakowskiego, wieś Nawarzyce i była w posiadaniu jej. Spór wytoczył się przed Opizona ${ }^{54}$, opata mezagneńskiego, ówczesnego w kraju legata apostolskiego. Za rada i powaga Prandoty, biskupa krakowskiego, na dniu 6 lipca 1247 r. nastapiła między spornymi stronami zgoda taka, że klasztor jędrzejowski odstappił dziekanowi i kapitule dziesięcinę $z$ wsi Tropiszowa ${ }^{55}$ wraz $z$ wsią Grębałowem ${ }^{56}$, a Nawarzyce zostały przy klasztorze. Za tę zamianę i na podniesienie $z$ upadku (in restaurum... czego?, czy klasztoru, czy Nawarzyc, czy kościoła?) klasztor otrzymał od biskupa i kapituły dziesięcinę $z$ wsi Nawarzyc i prawo do wszelkich dziesięcin $z$ nowizn, jakie w przyszłości mogą powstać w obrębie tejże wsi. $Z$ dokumentu, traktującego o powyższej zamianie, okazuje się, $\dot{z}$ e dziesięcina $z$ Nawarzyc przedtem należała do biskupa krakowskiego $^{18)}$. Toteż nie bez podstawy Długosz powiedział, że Nawarzyce były niegdyś własnością kapituły krakowskiej ${ }^{19)}$.

\section{[k. 7] Niegosławice}

Jak starożytna to miejscowość można przekonać się z tego, że już jest o niej mowa około roku $1167^{20)}$.

W kilkanaście lat potem pewien Niegosław pomieniał się z klasztorem jędrzejowskim na wiś Niegosławice w ten sposób, że za nią wziął wieś klasztorną Buszków ${ }^{57}$ z pewną dopłatą, jak 12 wołów, 3 krów, 2 koni zaprzęgowych, 1 wierzchowca, 7 stogów paszy i 30 korcy zboża ozimego, co wynosiło do 30 grzywien srebra. Zamianę potwierdził Fulko, biskup krakowski ${ }^{58}$, [w] 1192 r. i Kazimierz Sprawiedliwy, książę krakowski, sandomierski i lubelski ${ }^{21}$.

18) „Kodeks dyplomatyczny katedry św. Wacława”, t. I, s. 37.

19) „Liber beneficiorum”, t. III, s. 368.

20) „Kodeks” Bartoszewicza, s. 7.

21) „Kodeks dyplomatyczny Małopolski”, t. III, s. 8.

${ }^{54}$ Opizo (Opiz, Opizon) - opat klasztoru pw. św. Pawła w Mezzano, legat papieski w Polsce i w Prusach od około 1245 do 1254 r. Por. A. Naruszewicz, Historya narodu polskiego, t. VII, wyd. J.N. Bobrowicz, Lipsk 1836, s. 92, 95-97.

55 Tropiszowa, wieś w dawnym województwie krakowskim.

56 Grębałów, dawna wieś duchowna, obecnie w granicach miasta Krakowa.

57 Buszków, wieś w dawnym województwie krakowskim, 20 km na wschód od Miechowa.

${ }^{58}$ Pełka h. Lis, zw. też Fulko (zm. 1207), biskup krakowski w latach 1186-1207, bliski współpracownik i kanclerz księcia Kazimierza Sprawiedliwego. Por. 
Syn Niegosława, także imieniem Niegosław, nie był zadowolony $z$ transakcji ojcowskiej. Pozwał opata jędrzejowskiego i klasztor o zwrócenie wsi. Od wyroku sądowego, wydanego przez Pakosława, wojewodę krakowskiego ${ }^{59}$, poszła sprawa na wiec, odbywany w Mikulinie (w województwie mazowieckim) w maju 1212 r. Obecni na nim książęta Leszek Biały i Konrad, po rozpatrzeniu transakcji i tego, co wzią w naturze Niegosław, zawyrokowali: jeżeli pan Niegosław chce zerwać zamianę, niech zwróci wszystko w całości, co dostał od klasztoru, a będzie miał prawo do piątej tylko części wsi Niegosławic, jak na niego przypada; czego jeżeli zaniecha, ma co do tej sprawy zachować milczenie wieczyste ${ }^{22)}$.

[k. $7 v$ ] Niegosławice i Nawarzyce wraz z innymi posiadłościami klasztornymi Bolesław Wstydliwy przywilejem w roku 1256 uwolnił od podatku zwanego „stan”23).

Po kasacji klasztorów w roku 1817 przytoczone wyżej obydwie wsi przeszły na Rząd, a potem stały się donacja majoratu generała Ksawerego Czengierego ${ }^{60}$.

\section{Konary}

Długosz wyliczając wsi i dziesięciny $z$ nich należące do klasztoru jędrzejowskiego, mówi o Konarach, leżących między Niegosławicami a Bugniowem ${ }^{24}$. Widoczna, że zdanie swoje oparł na wyrażeniu Getki, biskupa krakowskiego ${ }^{61}$, w przywileju ...inter villam filiorum Bugiwoz et villam Nijegoslavi. Obecnie nie ma tu nigdzie Bugniowa, a dzisiejsze Konary graniczą na zachód z Strzeżkowicami.

22) Tamże, s. 13.

23) „Kodeks dyplomatyczny Małopolski”, t. III, s. 5.

24) „Liber beneficiorum”, t. III, s. 362.

J. Mitkowski, S. Trawkowski, Pełka (Fulko), [w:] PSB, t. XXV, Wrocław 1980, s. 571-574; P. Nitecki, op. cit., s. 340.

${ }^{59}$ Pakosław Stary, wojewoda krakowski w latach 1210-1212. Por. J. Bieniak, Pakosław Stary, [w:] PSB, t. XXV, s. 38-42.

${ }^{60}$ Ksawery Osipowicz Czengiery (1816-1880), generał rosyjski, uczestnik walk $\mathrm{w}$ powstaniu styczniowym.

${ }^{61}$ Gedko (1113-1185), biskup krakowski w latach 1166-1185. Por. K.R. Proko p, op. cit., s. 42-45. 
Gedko, biskup krakowski, będąc $z$ Janikiem, arcybiskupem gnieźnieńskim ${ }^{62}$, na konsekracji kościoła klasztornego XX. Cystersów w Jędrzejowie około roku 1167, zapisał temuż klasztorowi między innymi dziesięcinami i dziesięcinę $z$ Konar ${ }^{25}$. Długosz pisze $^{26)}$, że jeszcze Maur, biskup krakowski (1110-1118) $)^{63}$, konsekrując kościół w Brzeźnicy (dzi[k. 8]siejszym Jędrzejowie), już przeznaczył temu kościołowi dziesięcinę od stołu swego w Konarach. Sąsiedztwo po dziś dzień Konar z Niegosławicami, brak drugich Konar w okolicy tutejszej i Jędrzejowa, przemawia za tym, że we wspomnianych nadaniach mowa o tutejszych Konarach, a stąd widzimy, jak stara to miejscowość.

Długi czas, 200 lat z okładem, Konary jak i sąsiednie wsi: Strzeżkowice, Piotrkowice itd. zostawały w rękach Dębińskich, piszacych się z Dębian, herbu Rawicz, o których napisał Paprocki: „dom starodawny i rozrodzony, $z$ którego wiele mężów znacznie zasłużonych rzeczypospolitej bywało"27). Obecnie Konary stanowią własność prywatna Zygmunta Wielopolskiego, margrabiego myszkowskiego z Chrobrza ${ }^{64}$.

\section{Dębiany}

Jest to mała wioska i folwark stanowiacy jedno dominium z Konarami. Dębińscy zapewne musieli go założyć, skąd i nazwa powstała.

Inne folwarki i wioski, jak Janów, Brzezinki i Sadki, nie mają za soba przeszłości historycznej, jako powstałe w ostatnich czasach na wykarczowanych lasach poklasztornych nawarzyckich, których liczono 1200 morgów.

25) „Kodeks dyplomatyczny” Bartoszewicza, s. 7.

26) „Liber beneficiorum”, t. III, s. 362.

27) „Herby rycerstwa polskiego”, s. 543.

62 Jan (Janik) h. Gryf (zm. po 1167), arcybiskup gnieźnieński od 1149 r., uprzednio zaś (w latach 1146-1149) biskup wrocławski. Por. L.M. Wój cik, op. cit., s. $25-28$.

${ }^{63}$ Por. Z. Bu d kow a, Maur (Maurus), [w:] PSB, t. XX, Wrocław 1975, s. 261-262; P. Nitecki, op. cit., s. 287.

${ }^{64}$ Zygmunt Andrzej Wielopolski (1833-1902), syn Aleksandra Wielopolskiego i jego drugiej żony Pauliny Apolonii Potockiej, prezydent Warszawy, radca stanu, XIV ordynat Ordynacji Pińczowskiej Myszkowskich. 
[k. 8v] O kościele

Kto i kiedy ufundował kościół w Nawarzycach, na te pytania nie mamy odpowiedzi. Mówiąc wyżej o braciach herbu Gryf, widzieliśmy ich szczodrobliwość dla chwały Bożej. Można by przypuszczać, że ów Andrzej, biskup płocki, o którym pisze Paprocki, że był wielce świątobliwy (singularis devotus) ${ }^{28)}$, wzniósł tu dom Boży ku czci swojego patrona św. Andrzeja Apostoła, bo pod tym tytułem stoi kościół, ale na to nie posiadamy żadnego dowodu. Jeżeliby się sprawdziły nasze twierdzenia, że Nawarzyce powstały w miejsce zaginionej Mozgawy i Lizin, wypadałoby, że przed rokiem 1242 stał tu już kościół św. Klemensa. Przez wyrażenie się Prandoty, biskupa krakowskiego, „in restaurum” w nadaniu dziesięciny z Nawarzyc klasztorowi jędrzejowskiemu, kto wie, czy nie należy rozumieć, że Prandota obligowal opata do podniesienia $z$ upadku zdezelowanego kościoła tutejszego, gdyż działo się to w siedem lat po napadzie tatarskim. Toteż albo wyrestaurowawszy spustoszony kościół, albo zbudowawszy nowy, opaci, jako dziedzice wsi, uważali się za fundatorów kościoła i przysługiwało im prawo patronatu i kolacji. Jednakże w „Monumentach Theinera”, mieszczacych w tomie pierwszym spis beneficjów diecezji krakowskiej, nie znajdujemy Nawarzyc, z czego wypływałby wniosek, [k. 9] że jeszcze w roku 1326 nie było kościoła w Nawarzycach. Długosz, bliższy świadek onych czasów, tyle tylko wspomniał o kościele tutejszym, że poświęcony św. Andrzejowi ${ }^{29)}$. Słowem, w usiłowaniach celem wyjaśnienia początku kościoła należy powtórzyć za Psalmistą: „Droga ich ciemnością i ślizawka" (Ps. 34,6).

A kościół ów był $z$ drzewa.

Z wizyty Kazimierskiego [w] 1595 r. niewiele dowiadujemy się o nim. Suma summarum, że był konsekrowany i nie posiadał bogactwa w skarbcu. Wszystkiego miał wówczas dwa kielichy srebrne niepozłocone, krzyż srebrny $z$ podstawą miedziana i monstrancję miedzianą.

W wizycie Oborskiego [z] 1664 r. czytamy, że w kościele stały trzy ołtarze, sufit i ściany były pomalowane. Przybył jeden kielich srebrny, ampułek srebrnych $z$ tackami pięć. Puszka była miedziana i ta sama dawniejsza monstrancja miedziana.

28) „Herby rycerstwa polskiego”, s. 124.

29) „Liber beneficiorum”, t. III, s. 368. 
Kościół ów przypadkiem spalił się w nocy dnia 6 lutego 1741 r., ocalała tylko zakrystia.

W miejsce spalonego, kosztem Bernarda Łaszewskiego, opata jędrzejowskiego ${ }^{65}$, zaczęto (lubo nieprędko) murować nowy, obecnie stojacy, $z$ kamienia i cegły, czyli tak zwany futrowany, w ten sposób, że cegłę dawano $[z]$ zewnattrz, w pośrodku kamienie. Wskutek tego ma mury grube, fundamentalne; [k. 9v] podobnie grube są sklepienia. Długość kościoła $z$ prezbiterium wynosi łokci polskich 37, szerokość łokci 20 i pół, a wysokość murów łokci 22. Prezbiterium, zakończone okragło, ma po jednym oknie $z$ północy i południa, a nawa ma ich po dwa; nadto od zachodu jest jeszcze okno okragłe. Od zachodu, u wielkich drzwi, miał stanąc portyk, podobnie jak prezbiterium owalny (może wsparty na kolumnach), ale go, jak się zdaje dla braku funduszów, nie postawiono. Żyja jeszcze w parafii ludzie pamiętający już położone od dawna podobnie fundamenta pod niego. Fasadę, wznosząca się nad dach, zakończają wielkich rozmiarów różne ozdoby, jak wazony itd. rzeźbione $z$ kamienia. Nie brak ich i nad druga fasada, oddzielająca nawę od prezbiterium. $Z$ północnej strony prezbiterium stoi zakrystia, przy niej krużganek sklepiony $z$ drzwiami na kazalnicę, a za nim kruchta. Przy kruchcie za czasów austriackich zbudowano $z$ drzewa kaplicę przedpogrzebową. Po jej zdezelowaniu się, za czasów ks. Grochalskiego ${ }^{66}$, kosztem Eleonory hrabiny Stadnickiej, dziedziczki Konar, zmurowano obecnie stojąca.

Nadmieniliśmy wyżej, że po pogorzeli dawnego kościoła nie zaraz rozpoczęto budowę nowego, obecnego. Mamy dowody, iż murowano go dopiero w czerwcu 1747 r., na łuku zaś sklepienia w prezbiterium wyczytujemy rok 1753. Przyczyny powol[k. 10]nej budowy trzeba dopatrywać w tym, że ks. Ceypler ${ }^{67}$, założywszy fundamenta kościelne, zmarł czy w parę tygodni, czy w parę miesięcy, bo nie posiadamy dokładnej daty śmierci jego. Za nim poszedł też do grobu wkrótce Bernard Łaszewski, główny fundator. I o jego śmierci

${ }^{65}$ Bernard Łaszewski h. Grzymała (ok. 1690-1753), opat jędrzejowski w latach 1723-1753. Por. W. Bukowski, op. cit., s. 203.

66 Julian Grochalski (zm. 1854), profesor kieleckiego seminarium duchownego, proboszcz w Nawarzycach w latach 1851-1854. Wiadomości biograficzne por. Opisanie historyczne kościoła parafialnego w Nawarzycach..., k. 31v.

${ }^{67}$ Wojciech Ceypler, dziekan kapituły kieleckiej, scholastyk i dziekan kolegiaty pw. Wszystkich Świętych w Krakowie, proboszcz parafii Nawarzyce od 1720 do 1744 lub 1745 r. Obszerny biogram tego kapłana por. ibidem, k. 21v-25. Por. też J. W iśn niew ski, Historyczny opis kościołów..., s. 316. 
nie mamy dokładnej wiadomości. To wiemy, że następca Jan Wojciech Ziemnicki ${ }^{68}$ objął rządy opackie klasztoru jędrzejowskiego [w] $1750 \mathrm{r.}^{30)}$ Budowano powoli i długo, ale za to wzniesiono w stylu odrodzenia wspaniały dom Boży, który do piękniejszych okazów budownictwa kościelnego niewatpliwie zaliczyć należy.

Murował go Grzegorz Jajkiewicz vel Jajczyński, mieszkaniec miasta Krakowa, podmajstrzy murarski. W roku 1749 tytułował się wicemajstrem fabryki (rozumie się kościelnej, bo mowa o Nawarzycach). Nie wiedzielibyśmy wcale o żadnym majstrze, gdyby nie to, że parafianie nawarzyccy prosili go kilka razy w tym czasie na kumotra nowo narodzonych swoich dzieci. W tychże metrykach chrztów jest raz wspomniany, mianowicie [w] 1750 r. Fryderyk Jędrowski z Książa Wielkiego, majster murarski. Tyle wszystkiego wyszukaliśmy o majstrach kościelnych.

Do harmonii przyczynia się tu wielce utrzymanie w odpowiednim stylu ołtarzy, których jest trzy: wielki [ $k$. 10v] w prezbiterium i dwa boczne w nawie.

Stanąwszy wewnątrz świątyni, mamy przed sobą ołtarz wielki, dużych rozmiarów, $z$ głównym obrazem, podobnych rozmiarów, św. Anny. Na zasuwie obraz Pana Jezusa konającego na krzyżua . $\mathrm{Na}$ mensie wspaniałe tabernakulum rzeźbione. Między kolumnami ołtarza stoją dwie figury wielkości naturalnej, przedstawiające św. św. Piotra i Pawła Apostołów.

Następnie, $\mathrm{w}$ ołtarzu, stojącym $\mathrm{w}$ nawie $\mathrm{z}$ południowej strony, widzimy główny obraz przedstawiajacy Zbawiciela; na zasuwie św. Sebastiana Męczennika, a w górnej kondygnacji św. Jana Kantego.

Trzeci i ostatni ołtarz ma w głównym obrazie Rodzinę Świętą; na zasuwie św. Andrzeja Apostoła, patrona parafii, a w wyższej kondygnacji bł. Wincentego Kadłubka.

Lubo wyliczone obrazy malowane sa dobrze, jednak nietrudno zauważyć inną rękę w obrazach wielkiego ołtarza, inszą w obrazach głównych ołtarzy bocznych, a jeszcze inakszą na zasuwach.

30) „Kazanie przy obłóczynach Józefy Lisieckiej, skarbnikówny liwskiej, miane 1761 r. przez X. Kassyana Korczyńskiego, Franciszkanina”, drukowane w Krakowie.

a Następuje skreślone zdanie: „Szkoda, że pozycja ciała Pana Jezusowego, wielkości naturalnej, jest tak zwana obecnie jansenistowska".

68 Jan Wojciech Ziemnicki h. Złota Wolność, przeor, a następnie opat jędrzejowski (1754-1771). Por. W. Bukowski, op. cit., s. 203. 
Nie wiadomo, kto je malował. Inwentarze kościelne dają im ogólną nazwę „obrazów włoskich".

Po ścianach kościoła wiszą obrazy czterech [ $k$. 11] ewangelistów w ramach rzeźbionych, suto złoconych, pięciołokciowej wysokości, malowane przez Franciszka Ignacego Molitora ${ }^{69}[\mathrm{w}] 1770$ r., jak świadczy umieszczony napis.

Na ścianie przy wejściu do zakrystii wisi obrazek Matki Boskiej Bolesnej, malowany na blasze. Powiadają, że ma być szkoły hiszpańskiej. Niegdyś miał zawieszone wotum.

Obejrzawszy się teraz poza siebie, widzimy chór gustowny, ozdobiony rzeźbami, a na nim organek o ośmiu głosach $z$ piękna strukturą.

Wszystko, cośmy powiedzieli dotąd o upiększeniu wewnętrznym kościoła, zacząwszy od budowy ołtarzy, stanęło staraniem, a zdaje się, że i kosztem ks. Jana $z$ Matty Kotańskiego ${ }^{70}$, doktora filozofii, profesora Akademii Krakowskiej, miejscowego plebana. Nie dosyć na tym.

W pierwszej wnęce kościoła, z północnej strony, stoi ambona, snycerska robota cała wykonana, godna widzenia. Zrobiona jest na kształt łódki morskiej, którą unoszą cztery syreny, wychylające się $z$ fal morskich. Na korpusie łodzi jest rzeźba, przedstawiająca Pana Jezusa płynącego na łodzi z apostołami. W samym zaś szczycie, między promieniami, Dobry Pasterz dźwigający owieczkę na swoich ramionach.

Naprzeciw kazalnicy stoi chrzcielnica, także cała rzeźbiona $z$ drzewa. Zrobiona jest na kształt [k. 11v] wanny, onego labrum Starego Zakonu, wspartego na czterech lwach. Na froncie widać arcykapłana sprawującego obrzęd obrzezania. Pod spodem wąż piekielny $z$ jabłkiem, a nad chrzcielnica wisi na ścianie obraz w ozdobnych ramach, przedstawiajacy chrzest Pana Jezusa. Tę to chrzcielnicę i ambonę wyżej opisaną sprawił Adam hrabia na Przerębie Przerębski, opat komendatoryjny jędrzejowski, z masy po śmierci ks. Kotańskiego.

${ }^{69}$ Franciszek Ignacy Molitor, malarz krakowski działający na dworze króla Stanisława Augusta Poniatowskiego. Jego uczniem był m.in. Michał Stachowicz.

70 Jana z Matty Kotański (zm. 4 XI 1782), proboszcz parafii nawarzyckiej w latach 1758-1782. Więcej na jego temat por. Opisanie historyczne kościoła parafialnego w Nawarzycach..., k. 27-29. 
W drugiej parze wnęk kościoła wiszą dwa duże obrazy, oprawne w ramy rzeźbione, św. Jana Nepomucena i św. Iwona kapłana, obrońców sekretu spowiedzi. Wyżej wspomniany Przerębski wzią je do Krakowa czy do restauracji, czy też piękniejszego przemalowania; a gdy wkrótce zmarł, o mało że nie przepadły. Niegdyśs niżej ich stały dwa konfesjonały.

W końcu wstapiwszy do zakrystii, lubo tu zawsze znajdujemy wzorową czystość, sporą ilość aparatów kościelnych i w należytym porządku utrzymanych, jednak nie znajdujemy ani jednego, który by mógł być zaliczony do rzadszych okazów. Podobnie nie ma żadnych napisów ani herbów między argenterią ${ }^{71}$.

Poznany w ten sposób kościół nie był konsekrowany. Za staraniem dopiero obecnego plebana parafii, ks. Kajetana Świderskiego $^{72}$, w dniu 20 maja, czyli w pierwszy dzień Zielonych Świątek 1888 r., Naj[k. 12] dostojniejszy nasz Pasterz, ks. Tomasz Teofil Kuliński, biskup diecezji kieleckiej ${ }^{73}$, przy licznym zjeździe duchowieństwa i wielkiego konkursu ludzi, dokonał aktu konsekracji kościoła, przydając do dawnego tytułu kościoła św. Annę za współpatronkę i przeznaczając niedzielę druga po Wniebowzięciu Matki Bożej na rocznicę poświęcenia kościoła. Uwieczniono ten ważny fakt do dziejów każdej parafii przez wmurowanie w ścianę kościelna płyty marmurowej $z$ odpowiednim napisem.

W pięć lat potem wydarzył się z kościołem smutny wypadek. W dniu 23 maja 1893 r., w czasie odprawiania się w kościele nabożeństwa majowego, wybuchł ogień w budynku p. Czerneckiej ${ }^{74}$, przytykającym do cmentarza kościelnego. Kierowany siłą wiatru

${ }^{71}$ Argenteria (łac.), przedmioty srebrne, srebra kościelne.

72 Kajetan Świderski (1830-ok. 1907), kapłan diecezji kieleckiej, wyświęcony w 1855 r. Był poczatkowo wikariuszem w Nowym Korczynie, od 1856 r. administratorem parafii Skarżyce, a od 1866 r. administrował parafią w Nawarzycach. Por. ADK, Akta konsystorskie. Status cleri 1847-1929, sygn. OP-X/13, s. 1014-1015; oraz J. Wiśn niew s ki, Historyczny opis kościołów..., s. 317 (tu rok 1906 jako data zgonu ks. Świderskiego). O działalności K. Świderskiego na parafii nawarzyckiej por. Opisanie historyczne kościoła parafialnego w Nawarzycach..., k. 32-33v.

73 Tomasz Teofil Kuliński (1823-1907), biskup diecezji kieleckiej w latach 1883-1907. Por. M. Żyw czyński, Kuliński Tomasz Teofil (1823-1907), [w:] PSB, t. XVI, Wrocław 1971, s. 160; J. Szczepański, Sylwetki biskupów kieleckich, [w:] Pamiętnik Świętokrzyski. Studia z dziejów kultury chrześcijańskiej, red. L. Kaczanowski et al., Kielce 1991, s. 333-336; D. Wojciechowski, Działalność duszpasterska biskupa kieleckiego Tomasza Kulińskiego (1870-1907), „Nasza Przeszłość" 1982, t. LVII, s. 9-44.

${ }^{74}$ Czerniecka, włościanka z Nawarzyc, skądinąd nieznana. 
w stronę kościoła, ogień dostał się na dach kościelny, gontowy; a po silnym upale słonecznym dnia tego, wnet cały kościół stanął w płomieniach. $Z$ wysokości kościelnej wiatr, unosząc perzyny i iskry ognia, zapalił dom służby kościelnej, świeżo w roku poprzednim pokryty. Między dwoma ogniami znajdująca się dzwonnica drewniana, także przed rokiem nowo oszalowana, zajęła się w końcu. Myśleć o jakimkolwiek ratunku było niepodobieństwem. Kto nie pobiegł na ratunek własnej chudoby, bo i na wsi w tymże kierunku wiatru tliło się już na budynkach, ten $z$ miejscowym plebanem wynosił aparata i inne sprzęty kościelne. Ogień dostał się do ko[k. 12v]śsioła przez okno od strony północnej, ale dzięki sklepieniom kościelnym wewnattrz nie poczynił znaczniejszych strat. Skończyło się na tym, że spalił się do cna cały dach kościelny wraz $z$ wieżą kościoła; dachy na zakrystia, kruchta i kaplica przedpogrzebową; dom służby kościelnej i dzwonnica, a $z$ nią stopiły się trzy dzwony ${ }^{31)}$. $Z$ nich duży miał napis: „Me fecit Joh(ann) Gottfried Anthony. Gedani. 1747”, a mały: „Ave Maria Maria Maria [s] Dominus Tecum".

Przywaleni ogromem takiego nieszczęścia wszyscy, i dwory, i włościanie, wzięli się energicznie i jednomyślnie do składek pieniężnych i robót zwózkowych bezpłatnie. Po wielu uciażliwych trudach, przy pomocy Bożej, zdołano przed zimą dać nowe dachy kościelne i postawić wieżę na kościele, podobną zupełnie do spalonej, co wszystko pokryto blachą cynkowa. Koszty wszystkich wydatków wyniosły ogółem 3684 rub. 22 i pół kop.; w czym mieści się 100 rub. ofiarowane dobrowolnie przez p. Tomasza Winnickiego, dzierżawcę Niegosławic i Nawarzyc ${ }^{75}$, i drugie 100 rub. ofiarowane przez p. Karola Malskiego, dziedzica Sędowic ${ }^{76} z$ obcej parafii.

Ukończywszy roboty około kościoła, w roku następnym, za pieniądze wzięte za asekuracją $z$ dodatkiem przez parafian, zbudowano dom nowy dla służby kościelnej.

Z funduszów brackich, do czego przyłożył się p. Ste[k. 13]fan Wielowiejski ${ }^{77}$ ofiara 25 rub. i Stanisław Łachowski ${ }^{78}$, cechmistrz, ofiarowaniem 17 rub., sprawiono dzwony następujące:

31) „Słowo”, nr 119, 1893 r. i „Przegląd Katolicki”, nr 23.

75 Tomasz Winnicki h. Sas, dzierżawca Niegosławic i Nawarzyc.

${ }^{76}$ Sędowice, w XIX w. wieś i folwark nad rzeka Mierzawa, w powiecie jędrzejowskim, gminie Nawarzyce, parafii Wrocieryż.

77 Stefan Wielowiejski (1865-1931), bankier i polityk, właściciel majątku Lubcza.

78 Stanisław Łachowski, bliżej nieznany. 
1) duży, lany na miejscu $z$ materiału po stopionych dzwonach w czasie pożaru kościoła $z$ dodaniem kilkudziesięciu funtów miedzi, ofiarowanych przez p. Adama Wielowiejskiego, dziedzica Lubczy, prezesa Towarzystwa Kredytowego Ziemskiego w Kielcach. Waży 441 funtów. Pomieszczono na nim napis: „S. Andreas Patronus Ecclesiae. Fecit I. Zuch ${ }^{79}$ M.DCCC.XC.IV”. Przelanie kosztowało 87 rub. i 15 kop.

2) mniejszy, wagi 267 funtów, z napisem: „S. Anna Patrona Parochiae Nawarzycen. 1894 a”. Kosztuje 168 rub. i kop. 50, od A. Zwolińskiego ${ }^{80} \mathrm{w}$ Warszawie.

3) mały, sprowadzony jak poprzedni z Warszawy, ważący 53 funtów, kosztuje 36 rub. 15 kop. ${ }^{81}$

4) sygnaturka, 31 funtów, kosztuje 18 rub. 18 kop.

Zawieszono je w tymczasowo postawionej ze słupów dzwonnicy. Mówiąc o dzwonach, nadmieniam jeszcze, że dzwonek przy zakrystii $z$ roku 1786 ma napis: „Laudatur Sanctissimum Sacramentum in saeculum".

\section{O odpustach}

Kościół nawarzycki ma odpusty wiecznymi czasy od Stolicy Apostolskiej w dniu 20 lipca 1787 r. nadane i przez Urząd Generalny Biskupi $[k .13 v]$ Krakowski utwierdzone na uroczystości: św. Andrzeja Apostoła, św. Anny i Opieki św. Józefa.

Nadto ma przywilej wiecznymi czasy dany od Stolicy Apostolskiej z dnia 30 lipca 1793 r., a podobnie przez Urząd Biskupi Krakowski utwierdzony, którym ołtarz wielki św. Anny wiecznie uprzywilejowany za dusze zmarłych.

79 Jan Zuch, ludwisarz z Wiślicy, czynny w drugiej połowie XIX w.

80 Michał Antoni Zwoliński (1846-1912), ludwisarz warszawski.

${ }^{81}$ Dwa $z$ tych instrumentów, mały o wadze 53 funty i większy „kilkusetfuntowy”, zostały zarekwirowane przez władze austriackie 17 VIII 1916 r. Por. Ks. Józef Zalech (?), dziekan jędrzejowski do Konsystorza Biskupiego w Kielcach, Krzcięcice 3 I 1917, ADK, Akta konsystorskie. Dzwonów zabranie podczas wojny 1831-1922, sygn. OG-10/12, k. 206v. Por. też Wykaz zajętych dzwonów w diecezji kieleckiej, ibidem, k. 243v. 
$\mathrm{Na}$ powyższe odpusty znajdują się dokumenty pergaminowe. Postarał się o nie ks. Dominik herbu Kolumna Walewski ${ }^{82}$, proboszcz miejscowy.

\section{O uposażeniu kościoła}

Uposażenie plebanii w Nawarzycach składało się $z$ dziesięcin, gruntów i łąk.

Według „Liber Retaxationum” z roku 1529 te należały dziesięciny: w Konarach $z$ gruntów dworskich dziesięcina wytyczna; w Żernikach (parafii brzegowskiej) $z$ połowy wsi dziesięcina wytyczna; w Nawarzycach $z$ trzech łanów takaż dziesięcina i kolęda pieniężna.

Po inkorporacji parafii lubeckiej [1690], przybyły plebanom nawarzyckim dziesięciny, niegdyś do niej należące.

Co do gruntów, leżały one w kilku miejscowościach:

1) rola na Starym Gaju zwana

2) grunt między polem dworskim

3) grunt za dworem plebańskim zwany

4) grunt Połanek waski zwany

5) rola prosto Lipek zwana

6) pole za Folwarkiem Zakrzew zwane

7) ogród na Adamowie

8) ogród dla organisty

9) ogród za folwarkiem plebańskim

10) ogród za spichrzem dawniej

Chmielnik zwany

11) sad $z$ pszczelnikiem

12) łąka za ogrodem plebańskim

13) łąka przy ogrodzie Adamowskim zwana

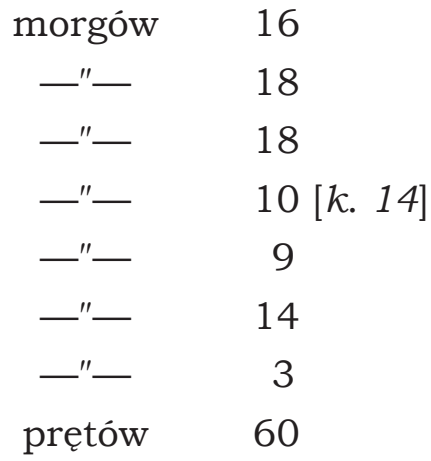

morga 1 prętów 20

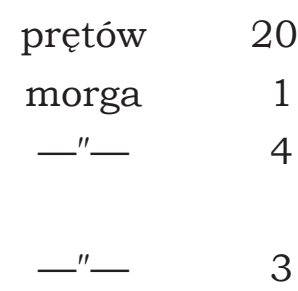

${ }^{82}$ Dominik Walewski h. Kolumna (1756-1806), kanonik inflancki i pułtuski, proboszcz w Nawarzycach w latach 1783-1806. Informacje biograficzne: Opisanie historyczne kościoła parafialnego w Nawarzycach..., k. 29-29v (tu wzmianka, że Dominik zmarł 10 VI 1806 r.). Por. też M. Kobierecki, Walewscy herbu Kolumna w XVII-XVIII wieku. Genealogia. Majętności. Działalność publiczna, Łódź 2008, s. 117-120, zwłaszcza 125 (tu inna dzienna data śmierci tego kapłana - 8 VI). 
Pięciu poddanych plebańskich trzymało ogółem morgów 15.

Słowem, według rejestrów pomiarowych po urządzeniu kolonialnym, dopełnionym [w] 1858 r., pokazało się, że probostwo nawarzyckie miało ogółem $z$ tym, co trzymali poddani, 115 morgów miary nowopolskiejej i prętów 63.

$Z$ biegiem czasów plebanii uzyskali prawo pasania inwentarza na wspólnych pastwiskach, wolny wrąb do lasów nawarzyckich i wolną propinację.

Mieli też jeszcze na Niegosławicach „Meszne” (nie wiadomo, kiedy powstało), którego dwór powinien oddawać pszenicy korcy 8, a każdy kmieć po 2 ćwierci miary sandomierskiej. W roku 1792 liczono kmieci 14.

Słowem, dochody plebanii tutejszej w czasie lat żyźniejszych, podług opisu wizyty generalnej w roku 1783 wylikwidowane, wynosiły ogółem [k. 14v] $3700 \mathrm{zł}$ brutto.

Trzeba nadmienić, że kościół tutejszy nie miał żadnych lokowanych kapitałów, zapisów, wskutek czego na duchowieństwie nie ciążyły obligi do odprawienia.

Wskutek ukazu Najjaśniejszego Aleksandra II, cesarza Wszechrosji i króla polskiego, pod dniem 14 (26) grudnia 1865 r. w Petersburgu wydanego, po zajęciu na skarb wszelkiej własności kościelnej, probostwo nawarzyckie zaliczone zostało do probostw nieklasowych, $z$ wyznaczeniem proboszczowi sześciu morgów gruntu i płacy etatowej 300 rs. rocznie ${ }^{\text {b }}$.

b Następuje wykaz proboszczów administrujących parafią w Nawarzycach.

${ }^{83}$ Miary nowopolskie, system miar Królestwa Polskiego wprowadzony 1 I 1819 r., oficjalnie stosowany do roku 1849, kiedy zastapiły go miary rosyjskie, choć $\mathrm{w}$ praktyce korzystano $\mathrm{z}$ niego także później. Według tej miary $1 \mathrm{morga}=5598,7 \mathrm{~m}^{2}$, a 1 pręt $=18,66 \mathrm{~m}^{2}$. 


\section{Bibliografia}

\section{ŹRÓDEA ARCHIWALNE}

Archiwum Diecezjalne w Kielcach [ADK]

Akta konsystorskie. Dzwonów zabranie podczas wojny 1831-1922, sygn. OG-10/12.

Akta konsystorskie. Opis kościołów dekanatu jędrzejowskiego 1884-1898, sygn. OD-8/3.

Akta konsystorskie. Status cleri 1847-1929, sygn. OP-X/13.

Akta konsystorskie parafii Nawarzyce 1806-1937, sygn. PN-5/1.

\section{ŹRÓDEA DRUKOWANE I WYDAWNICTWA ŹRÓDEOWE}

Corpus inscriptionu Poliniae, t. I (Województwo kieleckie), red. J. Szymański, z. 2 (Jędrzejów i region jędrzejowski), wydała, wstępem i komentarzem opatrzyła B. Trelińska, Kielce 1978.

Joannis Dlugossii Senioris Canonici Cracoviensis Opera omnia (= Jana Długosza kanonika krakowskiego dzieła wszystkie), vol. VIII (Liber beneficiorum dioecesis cracoviensis nunc primum e codice autographo editus, t. II), ed. A. Przeździecki, Cracoviae 1864.

Księga dochodów beneficjów diecezji krakowskiej z roku 1529 (tzw. Liber retaxationum), wyd. Z. Leszczyńska-Skrętowa, Wrocław 1968, Materiały Komisji Nauk Historycznych, nr 13.

Naruszewicz A., Historya narodu polskiego, t. VII, wyd. J.N. Bobrowicz, Lipsk 1836. Niesiecki K., Herbarz polski, t. IX, wyd. J.N. Bobrowicz, Lipsk 1842.

\section{OpRacowania}

Baczkowska W., Szczygielski W., Potkański Franciszek, [w:] Polski słownik biograficzny, t. XXVII, Wrocław 1983, s. 722-724.

Bieniak J., Pakosław Stary, [w:] Polski słownik biograficzny, t. XXV, Wrocław 1980, s. $38-42$.

Bieniarzówna J., Oborski Mikołaj, [w:] Polski słownik biograficzny, t. XXIII, Wroclaw 1978, s. 449-450.

Borkiewicz S., Linowski Z., Monografia historyczna i gospodarcza powiatu jedrzejowskiego, Kielce 1937.

Br. Ch. [Bronisław Chlebowski], Nawarzyce, [w:] Słowniku geograficznym Królestwa Polskiego i innych krajów słowiańskich, red. F. Sulimierski, B. Chlebowski, W. Walewski, t. VI, Warszawa 1885, s. 936.

Budkowa Z., Maur (Maurus), [w:] Polski słownik biograficzny, t. XX, Wrocław 1975, s. 261-262.

Bukowski W., Katalog opatów jędrzejowskich. Próba ustalenia chronologii, [w:] Cystersi w Polsce. W 850-lecie fundacji opactwa jędrzejowskiego, red. D. Olszewski, Kielce 1990, s. 179-204. 
Ihnatowicz I., Projekt instrukcji wydawniczej dla źródeł historycznych XIX i początku XX wieku, „Studia Źródłoznawcze” 1962, t. VII, s. 99-124.

Kaniewska I., Spinek (Wspinek) Stanisław, [w:] Polski słownik biograficzny, t. XLI, Warszawa-Kraków 2002, s. 107-109.

Katalog zabytków sztuki w Polsce, t. III (Województwo kieleckie), red. J.Z. Łoziński, B. Wolff, z. 3 (Powiat jedrzejowski), oprac. T. Przypkowski, Warszawa 1957.

Kobierecki M., Walewscy herbu Kolumna w XVII-XVIII wieku. Genealogia. Majętności. Działalność publiczna, Łódź 2008.

Kowalski M.D., Zapomniany kalendarz-nekrolog kapituły krakowskiej z XV wieku, „Nasza Przeszłość” 1997, t. LXXXVII, s. 123-145.

Kowalski T., Ambona łodziowa $w$ Sierpcu - geneza zjawiska artystycznego $i$ jego sierpeckie echa, „Notatki Płockie. Kwartalnik Towarzystwa Naukowego Płockiego" 2015, t. LX, nr 1(242), s. 16-21.

Kozłowska-Budkowa Z., Bolesław (1159-1195), [w:] Polski słownik biograficzny, t. II, Kraków 1936, s. 262.

Łukaszewicz J., Dzieje kościołów wyznania helweckiego w dawnej Małej Polsce, Poznań 1853.

Mitkowski J., Trawkowski S., Pełka (Fulko), [w:] Polski słownik biograficzny, t. XXV, Wrocław 1980, s. 571-574.

Nitecki P., Biskupi Kościoła $w$ Polsce $w$ latach 965-1999. Słownik biograficzny, wyd. 2 poprawione i uzupełnione, Warszawa 2000.

Pożar kościoła, „Przegląd Katolicki”, 8 VI 1893, R. XXXI, nr 23, s. 363.

Prokop K.R., Poczet biskupów krakowskich, Kraków 1999.

S.S. [Stefan Stuczeń?], Pożar kościoła, „Słowo”, 27 V 1893, R. XII, nr 119, s. 2.

Samek J., Ambony naves et naviculae w Polsce, [w:] Rokoko. Studia nad sztuka I połowy XVIII wieku. Materiały Sesji Stowarzyszenia Historyków Sztuki zorganizowanej wspólnie z Muzeum Ślaskim we Wrocławiu, Wrocław, październik 1968, Warszawa 1970, s. 219-250, http://www.samkoviana.pl/1970-50-ambony-naves-et-naviculae-w-polsce/ (dostęp: 15 VIII 2021).

Szczepański J., Sylwetki biskupów kieleckich, [w:] Pamiętnik Świętokrzyski. Studia $z$ dziejów kultury chrześcijańskiej, red. L. Kaczanowski, A. Massalski, D. O1szewski, J. Szczepański,, Kielce 1991, s. 329-343.

Szymański D., Wezwania kościołów parafialnych $w$ diecezji krakowskiej $w$ końcu XVI w., „Roczniki Humanistyczne” 1993, t. XLI, z. 2, s. 83-159.

Trawkowski S., Prędota (Prandota), mylnie Jan P-a, [w:] Polski słownik biograficzny, t. XXVIII, Wrocław 1984-1985, s. 447-452.

Umiński J., Andrzej I h. Gryf zw. Krakowczykiem, [w:] Polski słownik biograficzny, t. I, Kraków 1935, s. 102.

Urban W., Kazimirski (Kazimierski) Krzysztof, [w:] Polski słownik biograficzny, t. XII, Wrocław-Warszawa-Kraków 1966-1967, s. 292-293.

Wiśniewski J., Historyczny opis kościołów, miast, zabytków i pamiątek $w$ Jędrzejowskiem, Marjówka 1930 (reprint: Kielce 2000). 
Wiśniewski J., Katalog prałatów i kanoników sandomierskich od 1186 do 1926 r. tudzież sesje kapituły sandomierskiej od 1581 do 1866 r., Radom 1928.

Wojciechowski D., Działalność duszpasterska biskupa kieleckiego Tomasza Kulińskiego (1870-1907), „Nasza Przeszłość” 1982, t. LVII, s. 9-44.

Wójcik M.L., Ród Gryfitów do końca XIII wieku. Pochodzenie-genealogia-rozsiedlenie, Wrocław 1993.

Wróblewska E., Ludwisarnie Benningków, Wittwercków i Anthonych: studium z dziejów gdańskiego cechu odlewniczego, Warszawa 1999.

Zdanek M., Opat Teodoryk i cystersi jedrzejowscy $w$ 1. połowie XIII wieku, [w:] Cystersi - Jędrzejów - Ziemia Jędrzejowska. Wspólne dziedzictwo, red. K. Ślusarek, Jędrzejów-Kraków 2006, s. 51-67.

Żywczyński M., Kuliński Tomasz Teofil (1823-1907), [w:] Polski słownik biograficzny, t. XVI, Wrocław 1971, s. 160.

NOTKA O AUTORCE:

Dr Małgorzata Karkocha - adiunkt w Katedrze Historii Nowożytnej, w Instytucie Historii Uniwersytetu Łódzkiego.

Zainteresowania naukowe: historia nowożytna powszechna XVI-XVIII w., dzieje kultury i sztuki XVI-XVIII w., Francja w dobie Wielkiej Rewolucji (1789-1799), prasa okresu stanisławowskiego, epigrafika, kampanologia.

( $)$ malgorzata.karkocha@uni.lodz.pl 